\title{
Effects of Some Environmental Factors on Seed Germination and Spreading Potentials of Silybum marianum Gaertner
}

\author{
Pasquale Montemurro*, Mariano Fracchiolla, Antonio Lonigro \\ Dipartimento di Scienze delle Produzioni Vegetali, Università di Bari \\ Via Amendola 165/A, 70126 Bari, Italy
}

Received: 21 September 2006. Accepted: 18 October 2006.

\begin{abstract}
Silybum marianum Gaertner is spreading in many crops of Southern Italy, particularly in durum wheat, sugar beet and some vegetable crops. Information about its biology are useful to set up effective control strategies. Four experiments were carried out at the Crop Science Department of the University of Bari (Southern Italy). Two trials were conducted in Petri dishes and evaluated the effects of different light, temperature and osmotic stress conditions on the seed germination. Another trial evaluated the ability of seedlings to emerge from different depths. The effects of eight different sowing periods on the plant growth were assessed in the fourth experiment. The highest germination rate was found with constant temperatures of $25^{\circ} \mathrm{C}$ or $30^{\circ} \mathrm{C}$ and with alternating temperatures of 25 $15{ }^{\circ} \mathrm{C}$ for 8 and 16 hours respectively.

Germination was affected by the light and was significantly decreased at $0.2 \mathrm{Mpa}$ and completely inhibited at $-0.8 \mathrm{Mpa}$. Plant emergence was strongly reduced from a depth of more than $3 \mathrm{~cm}$. The plant size at the first bloom was reduced by postponing the sowing period from October to February. The same decreasing trend was observed in the number of flower heads and in the number of days required for the first bloom. Results can suggest some important strategies to manage this species. False sowing, followed by irrigation, can be recommended in summer, in order to obtain the highest seed germination. Since the emergence of this plant is very scarce from a depth of more than $3 \mathrm{~cm}$, ploughing can be effective to bury seeds in case of strong disseminations in order to reduce the infestation in the following crop.
\end{abstract}

Key-words: integrated weed control, weeds, weed biology.

\section{Introduction}

Silybum marianum Gaertner (milk thistle Asteraceae family) is a biennial hemicriptophyte herb native of the Mediterranean region and which has also spread in Central Europe, Central and East Asia, North and South America and Southern Australia. Plants emerge in early winter and form large rosettes from which stems $20-250 \mathrm{~cm}$ height later grow. The leaves, the stem and the florescences of this plant are thorny. The main stem is branched and each single littler stem ends in a solitary flower head, about $5 \mathrm{~cm}$ in diameter, made up of purple flowers. The whole plant size can range from 60 to $180 \mathrm{~cm}$ in height. Leaves are broad and dark green in colour; they present typical white patches along their veins. Each flower head produces about 200 seeds, with an average of 6,350 seeds per plant (Morazzoni and Bombardelli, 1995).

Seeds are flat, smooth and have poor windborn dispersal because they only have a rudimentary "pappus". They remain viable for nine years or more and their dormancy period is affected by temperature and moisture (Sindel, 1991).

Milk thistle is normally considered to be a ruderal that grows along roadsides and on wastelands and prefers highly fertile soils (Gabay et al., 1994).

S. marianum is a species that is also well 
known for its medicinal properties. Its main active chemical component is the silymarin, which is a combination of three flavonoids. Due to their properties, these compounds are also able to protect different organs and cells against several diseases. Silybin (part of the chemical structure of silymarin) is an antioxidant with antihepatotoxic properties (Kvasnicka et al., 2003).

This plant is also reported as being a noxious weed in several countries. It competes with crops both for water and for nutrients. Moreover, due to its large foliage, even an individual plant of $S$. marianum is able to cause a high crop displacement. Once established, it spreads rapidly. Roche (1991) reported that dense milk thistle stands in California pastures are able to produce up to 3.4 million of viable seeds per hectare and up to 4 tons of biomass.

Milk thistle has been listed, since 1851, in the first Southern Australia noxious weed list (Sindel, 1991).

Young (1978) reported this plant as becoming an important weed for the Californian agriculture.

According to Omtvedt (1984), S. marianum infests cultivations of Canada, South-western Oregon, California, Texas and Nebraska.

The species is also spreading in many crops of Southern Italy, particularly in durum wheat (Montemurro, 1992), sugar beet (Montemurro, 1995) and some vegetables like broccoli, cauliflower and fennel (Montemurro and Tei, 1998).

Most of the biological studies about milk thistle have been focused on improving its cultivation techniques, given the medicinal properties of this plant.

Spitzova (1984) in Czechoslovakia studied the seed germination rate and viability in relation to the storage conditions. The highest germination rate was found in seeds stored for 1 or 2 years at $15^{\circ} \mathrm{C}$ and $50 \%$ of relative humidity and then sown in spring.

Mel'nikova (1983) reported that the minimum and maximum constant germination temperatures for S. marianum are 10 and $35^{\circ} \mathrm{C}$, with optima at 20 or $25^{\circ} \mathrm{C}$. With fluctuating temperatures, the highest germination rate was found at $20-25$ or $20-30{ }^{\circ} \mathrm{C}(16 \mathrm{~h}$ low $+8 \mathrm{~h}$ high $)$.

Fresh milk thistle seeds seem to need an after-ripening period and germinate better at low rather than high temperatures. In general, Young (1978) suggested that the higher the in- cubation temperatures are, the longer the afterripening requirement is. The same author found that seedlings are able to emerge from up to 8 $\mathrm{cm}$ in depth.

This work is aimed at knowing more information about $S$. marianum biology more directly focused to explain the eco-physiological reasons of the increasing infestations of S. marianum in many arable lands. Particularly, the effects of some environmental aspects on seed germination ability and on morphological features of the plant are investigated. Given information could be used to establish emergence or crop-weed competition models and to know different aspects of soil seedbank dynamic. Hence, guidance on integrated control of milk thistle in many crops could be provided.

\section{Materials and methods}

Four trials were carried out at the Crop Science Department between 1997 and 1998. Mature seeds were used once collected from the Experimental Farm belonging to the Bari Faculty of Agriculture (South Italy) and stored in a laboratory at the temperature of $20{ }^{\circ} \mathrm{C}$.

\section{1st Trial - Effects of temperature and light}

The combined effects of different temperature and light conditions on seed germination capacity were evaluated. Seeds were put to germinate under the following conditions: 1) $25^{\circ} \mathrm{C}$ $\mathrm{x} 16 \mathrm{~h}$ and $15{ }^{\circ} \mathrm{C} \mathrm{x} 8 \mathrm{~h}$; 2) $25^{\circ} \mathrm{C}$ constant; 3) 30 ${ }^{\circ} \mathrm{C}$ constant; 4) $15^{\circ} \mathrm{C}$ x $16 \mathrm{~h}$ and $5{ }^{\circ} \mathrm{C} \mathrm{x} 8 \mathrm{~h}$; 5) $15{ }^{\circ} \mathrm{C}$ constant; 6) $10{ }^{\circ} \mathrm{C}$ constant; 7) $25{ }^{\circ} \mathrm{C} \mathrm{x} 16$ $\mathrm{h}$ and $5{ }^{\circ} \mathrm{C} \times 8 \mathrm{~h}$. Each of the specified conditions were tried in the dark and in alternating light and dark for $8 / 16 \mathrm{~h}$ respectively.

\section{2nd Trial - Effects of osmotic stress}

The influence of increasing osmotic stresses $\left(0.0 ;-210^{2} ;-410^{2} ; 610^{2} ;-810^{2}\right.$ and $\left.10^{2} \mathrm{kPa}\right)$ on seed germination rate was studied. Stress was supplied by adding water with different polyethylene glycol (PEG 8000) concentrations (0.0 - 11.9 - 17.8 - $22.4-26.2$ and $29.6 \mathrm{~g} \mathrm{l}^{-1}$ at $\left.25^{\circ} \mathrm{C}\right)$.

Achenes were kept to germinate at alternating environmental conditions of $25^{\circ} \mathrm{C}$ in the light for 16 hours and $15{ }^{\circ} \mathrm{C}$ in the dark for 8 hours. 
Both in the $1^{\text {st }}$ and in the $2^{\text {nd }}$ trial, seeds were placed in plastic Petri dishes lined with filter paper and then put in a thermostatically controlled growth chamber provided with light (OSRAM Powerstar HQI-E W/150). Before testing, seeds were superficially sterilized by dipping them for 10 minutes in a $10 \%$ solution of sodium hypo chlorite and rinsing them with deionised water.

Each of the compared treatments were replicated 4 times, using 50 seeds for each single replication.

Only seeds with visible hypocotyls and cotyledons were considered to have germinated; they were removed and counted daily. The Average Germination Time (AGT) was calculated according to the following formula given by Pieper (1952):

$$
A G T=\frac{\sum(n x g)}{N}
$$

where:

$\mathrm{n}=$ number of seeds germinated each day

$\mathrm{g}=$ number of days required for the germination

$\mathrm{N}=$ total number of germinated seeds.

\section{3rd Trial - Effects of burial depth}

The trial evaluated the ability of seeds to emerge from different depths. Seeds (n. 25) were buried at increasing depth $(0-3-6-9$ and $15 \mathrm{~cm})$ in pots $(30 \mathrm{~cm}$ of diameter and 40 $\mathrm{cm}$ of height) filled with sandy soil whose humidity was provided by keeping the bottom of the pots immerged in water. Each treatment was replicated four times. Pots were placed in a growth chamber at $25{ }^{\circ} \mathrm{C}$ constant. This temperature condition was chosen among those giving the highest germination rate in the first trial.

Seedlings showing both the cotyledons completely unfolded on the surface of the soil were considered to be emerged; they were counted daily and removed from the pots.

\section{$4^{\text {th }}$ Trial - Influence of sowing time on the plant growth}

The effects of eight different sowing periods (from October $20^{\text {th }} 1997$ to February 24 ${ }^{\text {th }} 1998$ ) on the plant growth were assessed. Seeds were allowed to germinate in Petri dishes at alternating conditions of $25-15{ }^{\circ} \mathrm{C}$ and sown in an experimental field at Agricultural Faculty of
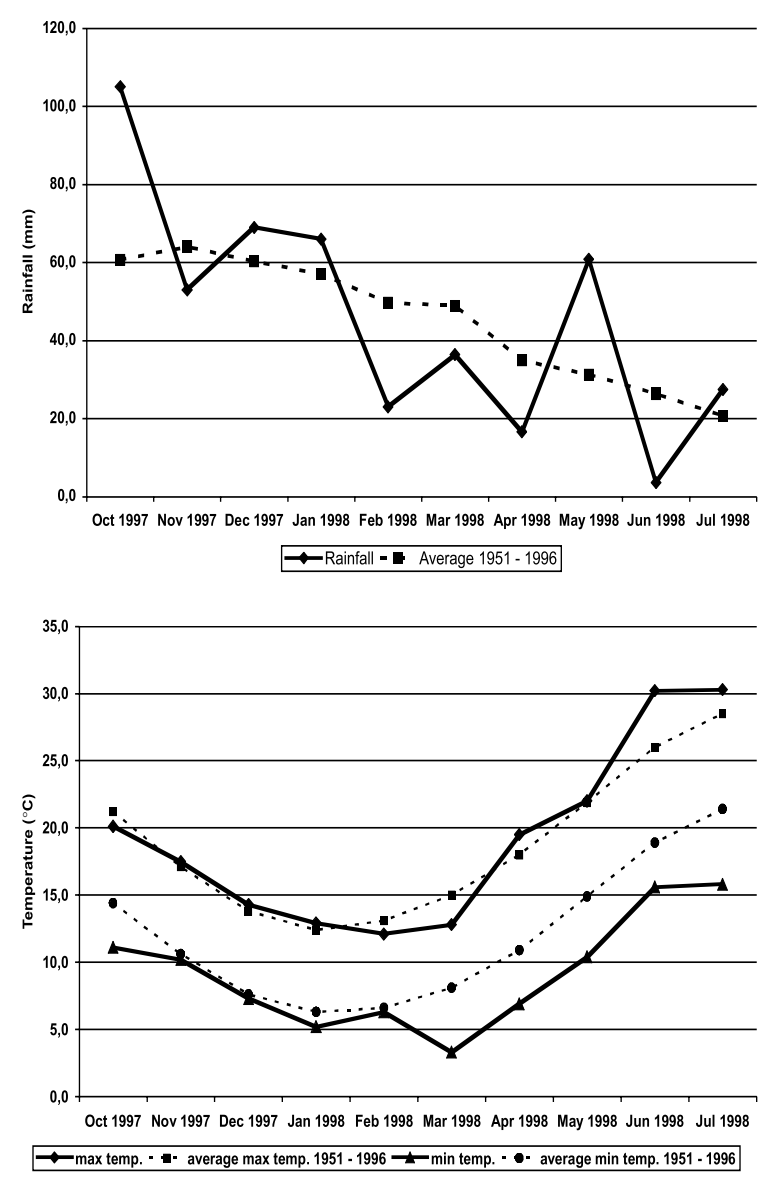

Figure 1. Climatic data during the experiment.

Bari, as soon as they showed the hypocotyls and the epicotyls.

In each plot, having a size of $1.0 \mathrm{~m}^{2}, 4$ seeds were sown and the following data were recorded: a) time required for the first bloom (first flower head completely open); b) plant height at the first bloom (from the surface of the soil to the top of the flower head); c) total number of flower heads produced by each plant.

Data from the plots were averaged on 4 plants and each thesis was replicated 4 times.

Climatic data (max/min temperatures and rainfall) were recorded during the experiment.

\section{Rainfall}

Figure 1 shows that rainfall was greater in October 1997 than in the other months. The lowest rainfall was recorded in June 1998, when 3.6 $\mathrm{mm}$ were recorded, whereas the least rainy 
month was February 1998 (-26.7 mm). During the other months, rainfall ranged from $69.0 \mathrm{~mm}$ (December 1997) to $16.6 \mathrm{~mm}$ (April 1998).

\section{Temperature}

Maximum temperature (Fig. 1) value was quite different from the long-term average in June $1998\left(+4.2^{\circ} \mathrm{C}\right)$. Minimum temperatures widely differed from the same long-term average in July $1998\left(-5.6{ }^{\circ} \mathrm{C}\right)$, March $1998\left(-4.8^{\circ} \mathrm{C}\right)$, May $1998\left(-4.5^{\circ} \mathrm{C}\right)$, April $\left.1998-4.0^{\circ} \mathrm{C}\right)$ and October $1997\left(-3.3^{\circ} \mathrm{C}\right)$.

\section{Statistical Analysis}

In the first trial, a split-plot experimental design was used, assuming the temperature as main factor.

The other trials were conducted in a randomized block experimental design.

The significance of differences between treatments was determined by Duncan's multiple range test or by Least Significant Difference (LSD).

\section{Results}

\section{1st Trial - Effects of temperature and light}

As shown in Table 2, germination rates at alternating temperatures of 25 and $15{ }^{\circ} \mathrm{C}$ and at the constant temperatures of 25 and $30{ }^{\circ} \mathrm{C}$ were 78.3 - 77.8 and $77.3 \%$ respectively; this data were statistically higher than the other conditions, whereas alternating temperature of 25 and $5{ }^{\circ} \mathrm{C}$ treatment gave the lowest seed germinability $(6.7 \%)$.

Germination rate was significantly higher in the light $(65.5 \%)$ than in the dark $(49.0 \%)$ condition (Tab. 2).

Examining the interaction between temperature and light, only at alternating temperatures of 25 and $5{ }^{\circ} \mathrm{C}$, light did not affect germination. Under the other temperature conditions, light supplying resulted in a higher germination rate. Particularly, at alternating temperatures of 15 and $5{ }^{\circ} \mathrm{C}$, light increased the germination rate by $23 \%$.

Table 3 shows that the longest average germination time $(21.3 \mathrm{~d})$ was obtained at alternating conditions of 25 and $5{ }^{\circ} \mathrm{C}$. Constant temperatures of 25 and $30{ }^{\circ} \mathrm{C}$ gave the shortest AGT, respectively equal to 2.3 and 3.0 days and not statistically different.
Table 2. Temperature and light effects on seed germinability.

\begin{tabular}{lccc}
\hline $\begin{array}{l}\text { Temperature } \\
\left({ }^{\circ} \mathrm{C}\right)\end{array}$ & \multicolumn{3}{c}{$\begin{array}{c}\text { Seed germinability } \\
(\%)\end{array}$} \\
\cline { 2 - 4 } & Dark & Light $\left({ }^{1}\right)$ & Average $\left({ }^{2}\right)$ \\
\hline $25 / 15(3)$ & 70.0 & 86.6 & $78.3 \mathrm{~A}$ \\
25 & 70.6 & 85.0 & $77.8 \mathrm{~A}$ \\
30 & 71.0 & 83.6 & $77.3 \mathrm{~A}$ \\
$15 / 5(3)$ & 48.6 & 80.6 & $64.6 \mathrm{~B}$ \\
15 & 45.0 & 71.6 & $58.3 \mathrm{~B}$ \\
10 & 29.0 & 46.6 & $37.8 \mathrm{C}$ \\
$25 / 5(3)$ & 9.0 & 4.6 & $6.7 \mathrm{D}$ \\
Average & $49.0 \mathrm{~B}$ & $65.5 \mathrm{~A}$ & \\
\hline
\end{tabular}

Interaction Temperature $\mathrm{x}$ Light: LSD at $0.01 \mathrm{P}=6.34$.

$\left({ }^{1}\right)$ Supplied for 8 hours.

$\left({ }^{2}\right)$ Values with no letter in common differ significantly at $0.01 \mathrm{P}$ (Duncan's test).

$\left(^{3}\right)$ Alternating for 8 hours and 16 hours respectively.

Regarding light effects, the AGT values, 8.6 $\mathrm{d}$ in the dark and $8.4 \mathrm{~d}$ in the light (Tab. 3), were not significantly different.

No interaction between temperature and light was detected by the statistical analysis.

2nd Trial - Effects of osmotic stress

As shown in Table 4, the highest germinability rate $(84.0 \%)$ was obtained with no osmotic stress. This value was significantly different from values obtained with the other treatments. Osmotic pressure of $-610^{2} \mathrm{kPa}$ gave a value equal to $1.0 \%$, not statistically different from $0.0 \%$ that was obtained with osmotic pressures of $-810^{2}$ and $-10^{2} \mathrm{kPa}$.

As for AGT (Tab. 4), values at 0.0 and $-210^{2}$ $\mathrm{kPa}$ resulted equal to 5.3 and 6.0 days respectively, significantly lower than those detected under the other osmotic conditions.

Table 3. Temperature and light effects on seed average germination time (AGT).

\begin{tabular}{lrcc}
\hline $\begin{array}{l}\text { Temperature } \\
\left({ }^{\circ} \mathrm{C}\right)\end{array}$ & \multicolumn{3}{c}{$\begin{array}{c}\text { Average germination time } \\
(\mathrm{d})\end{array}$} \\
\hline & Dark & Light $\left({ }^{1}\right)$ & Average $\left({ }^{2}\right)$ \\
\hline $25 / 5\left(^{3}\right)$ & 21.6 & 20.9 & $21.3 \mathrm{~A}$ \\
10 & 14.5 & 15.6 & $15.1 \mathrm{~B}$ \\
$15 / 5\left(^{3}\right)$ & 6.3 & 4.0 & $5.2 \mathrm{C}$ \\
$25 / 15\left(^{3}\right)$ & 7.4 & 5.8 & $6.6 \mathrm{C}$ \\
15 & 5.7 & 6.7 & $6.2 \mathrm{C}$ \\
25 & 2.2 & 2.3 & $2.3 \mathrm{D}$ \\
30 & 2.4 & 3.6 & $3.0 \mathrm{D}$ \\
Average & 8.6 & 8.4 & \\
\hline
\end{tabular}

$\left({ }^{1}\right)-\left({ }^{2}\right)-\left({ }^{3}\right)$ See Table 2. 
Table 4. Effects of different osmotic stresses on germination rate and average germination time (AGT) of seeds $\left(25^{\circ} \mathrm{C}\right.$ for 8 hours and 16 hours respectively and under 6000 lux light for 16 hours) ${ }^{(1)}$.

\begin{tabular}{ccc}
\hline $\begin{array}{c}\text { Osmotic } \\
\text { pressure } \\
(\mathrm{kPa})\end{array}$ & $\begin{array}{c}\text { Seed } \\
\text { germinability } \\
(\%)\end{array}$ & $\begin{array}{c}\text { Average } \\
\text { Germination } \\
\text { Time }(\mathrm{d})\end{array}$ \\
\hline 0.0 & $84.0 \mathrm{~A}$ & $5.3 \mathrm{a}$ \\
$-210^{2}$ & $68.0 \mathrm{~B}$ & $6.0 \mathrm{a}$ \\
$-410^{2}$ & $54.0 \mathrm{~B}$ & $8.1 \mathrm{~b}$ \\
$-610^{2}$ & $1.0 \mathrm{C}$ & $19.0 \mathrm{c}$ \\
$-810^{2}$ & $0.0 \mathrm{C}$ & - \\
$-10^{2}$ & $0.0 \mathrm{C}$ & - \\
\hline
\end{tabular}

${ }^{(1)}$ Values with no letter in common differ significantly at 0.05 (small letter) and at 0.01P (capital letter) (Duncan's test).

\section{3rd Trial - Effects of burial depth}

As reported in Table 5, seeds sown both at 0.0 and $3.0 \mathrm{~cm}$ gave the highest emergence rates, respectively equal to 70.0 and $67.5 \%$. These values were significantly different from those obtained with the other conditions in which emergence rates ranged from $22.5 \%(6.0 \mathrm{~cm})$ to $5.0 \%$ $(9.0$ and $15.0 \mathrm{~cm})$ and did not differ statistically one from the other.

\section{$4^{\text {th }}$ Trial - Influence of the sowing period on the plant growth}

Different sowing periods, from October $20^{\text {th }}$ to February $24^{\text {th }}$, gave decreasing values of plant heights, ranging from a maximum of $214.0 \mathrm{~cm}$ to a minimum of $102.0 \mathrm{~cm}$ (Fig. 2), all statistically different one from another, except for those plants that were sown on November $4^{\text {th }}$ and $19^{\text {th }}$.

Figure 2 shows that the highest number of flower heads per plant, equal to 56.0, was recorded for the plant sown on October $24^{\text {th }}$. This value was significantly different from the others. The number of flower heads on plants

Table 5. Burial depth effects on seed germinability $\left({ }^{1}\right)$.

\begin{tabular}{cc}
\hline $\begin{array}{c}\text { Seed burial depth } \\
(\mathrm{cm})\end{array}$ & $\begin{array}{c}\text { Seedling Emergence } \\
(\%)\end{array}$ \\
\hline 0.0 & $70.0 \mathrm{~A}$ \\
3.0 & $67.5 \mathrm{~A}$ \\
6.0 & $22.5 \mathrm{~B}$ \\
9.0 & $5.0 \mathrm{~B}$ \\
15.0 & $5.0 \mathrm{~B}$ \\
\hline
\end{tabular}

( ${ }^{1}$ Values with no letter in common differ significantly at $0.01 \mathrm{P}$ (Duncan's test).
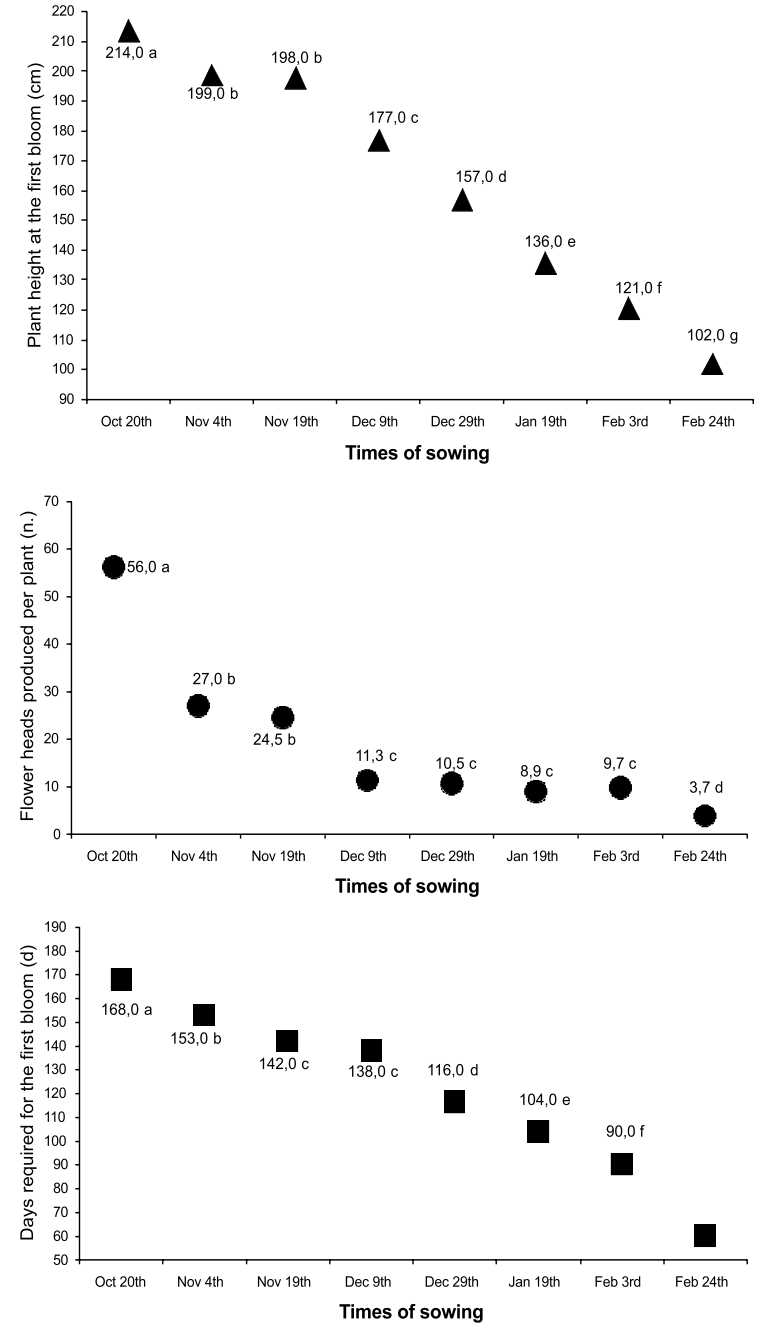

Figure 2. Influence of the sowing period on the plant growth, the number of flower heads produced per plant and on the days required for the first bloom. Values with no letter in common differ significantly at 0.01P. (Duncan's test).

sown from December until February $3^{\text {rd }}$ was not significantly different. Plants that were sown in February $24^{\text {th }}$ gave the lowest yield.

With regards to the days required to produce the first bloom, the highest value was detected for the plants sown in October $20^{\text {th }}(168.0 \mathrm{~d})$ and the lowest one $(60.0 \mathrm{~d})$ was observed for those sown in February $24^{\text {th }}$. Moreover, these values decreased statistically from October $20^{\text {th }}$ until February $24^{\text {th }}$, with the exception to November $19^{\text {th }}$ and December $9^{\text {th }}$, that gave origin to values that were not significantly different one from the other (142.0 and 128.0 days). 


\section{Discussion}

Results show that Milk Thistle seed germination is affected by light and temperature conditions. In particular, the highest germination is obtained with constant temperatures of 25 or $30{ }^{\circ} \mathrm{C}$ and with alternated temperatures of 25 to $15{ }^{\circ} \mathrm{C}$ for 8 and 16 hours respectively. Moreover, the AGT is very short under the abovementioned temperature conditions; whereas both the lowest constant temperatures and the alternated conditions of 25 and $5{ }^{\circ} \mathrm{C}$ delay the average germination period of about two weeks.

The osmotic stress as well significantly affects the germination that is strongly reduced at $-0.6 \mathrm{kPa}(-99 \%)$ whereas the AGT is delayed of about 14 days. Osmotic stress of $-0.8 \mathrm{kPa}$ completely inhibits the germination.

Plant emergence is highly reduced when seeds are buried at $6 \mathrm{~cm}$, or more, in depth.

As for the growth dynamics, the plant size at the first bloom is reduced by postponing the sowing period from October to February. The same decreasing trend is observed in the number of flower heads and in the days required for the first bloom.

Given results could be useful to suggest some integrated control strategies for this noxious weed.

False sowing followed by irrigation can be recommended in summer, in order to obtain the highest seed germination. Furthermore, it is better to advise growers to eliminate plantlets without ploughing the soil, using herbicides or flaming, not to bring other seeds up on the soil surface.

Rotation could be planned preferring spring-summer crop. During these seasons, Milk Thistle is smaller and therefore less competitive; moreover, surviving plants produce a lower number of flower heads and, as a consequence, of seeds.

Since the emergence of this plant is very scarce when seeds are buried at a depth of more than $3 \mathrm{~cm}$, ploughing can be effective to bury seeds in case of strong disseminations in order to reduce the infestation in the following crop.

\section{References}

Carrubba A., La Torre R., La Torre R. 2003. Cultivation trials of milk thistle (Silybum marianum Gaertn.) into the semiarid Mediterranean environment. Agricoltura Mediterranea, 133(1):14-19.

Gabay R., Plitmann U., Danin A. 1994. Factors affecting the dominance of Silybum marianum L. (Asteraceae) in its specific habitats. Flora, 189:201-206.

Kvasnicka F., Biba B., Sevcik R., Voldrich M., Kratka J. 2003. Analysis of the active components of silymarin. Journal of Chromatography $A$, 990:239-245.

Mel'nktov T.M. 1983. Morphological-biological characteristics of Silybum marianum seeds as sowing material. Khimiko-Farmatsevticheskii Zhurnal 17(8): 958-963.

Montemurro P. 1992. Stato attuale della flora infestante del frumento in Puglia e in Basilicata. Orizzonte Verde, 4, 3:17-20.

Montemurro P. 1995. Geografia delle infestanti. Terra e Vita, 36, 34:74-79.

Montemurro P., Tei F. 1998. Il controllo della flora infestante nelle colture orticole: problematiche agronomiche. In: Atti Convegno SIRFI, 12-13 Novembre 1998, Bari, 1-61.

Morazzoni P., Bombardelli E. 1995. Silybum marianum (Carduus marianus). Fitoterapia, 66 (1):3-42.

Omtvedt I.T. 1984. A Descriptive Guide for Major Nebraska Thistles. Agricultural Experimental Station. University of Nebraska - Lincoln. SB493.

Pieper H. 1952. Das Saatgut. Berlin.

Roche' C. 1991. Milk thistle (Silybum marianum (L.) Gaertn.). Pacific Northwest Extension Publication. Washington State University, Oregon State University and University of Idaho Cooperative Extension.

Sindel B.M. 1991. A review of the ecology and control of thistles in Australia. Weed Research, 31:189-201.

Sptzova I. 1984. Germination, course and rate of seed germination in milk thistle (Silybum marianum L. Gaertn.). Zahradnictvi, 1(4):322-329.

Young J.A., Evans R.A., Hawkes R.B. 1978. Milk thistle (Silybum marianum) seed germination. Weed Science, 26(4):395-398. 